\title{
SOME LEGAL ASPECTS OF WARTIME LABOR MOBILIZATION
}

\author{
Bernice Lotwin* and Reginald G. Conlex†
}

Compulsory manpower mobilization may be described as those forms of governmental control or regulation which are designed to achieve maximum utilization of the manpower of a nation in the armed forces, the production of materials needed for the prosecution of a war and the maintenance of essential civilian needs. ${ }^{1}$ A labor mobilization program may begin with the division of the total available manpower between the armed forces and civilian activities. ${ }^{2}$ The program may ultimately

* Ph.D., 1929, University of Wisconsin; LL.B., 1932, University of Wisconsin. Assistant General Counsel, War Manpower Commission; formerly, Assistant General Counsel, Federal Security Agency.

+ B.A., I933, University of Virginia; LL.B., 1935, University of Virginia. Principal Attorney, Office of General Counsel, War Manpower Commission; formerly, Attorney, Office of General Counsel, Federal Security Agency.

This article was prepared by the authors prior to their affiliation with the War Manpower Commission. It reflects only their personal views and is in no respect to be interpreted as reflecting the official views of either the Federal Security Agency or the War Manpower Commission.

${ }^{1}$ As of this date no direct compulsory measures, statutory or otherwise, have been instituted in the field of labor mobilization. The occupational deferment provisions of the Selective Training and Service Act of $x 940,54$ STAT. 885, 50 U. S. C. \$30x, hereinafter referred to as "The Sclective Scrvice Act of r940," constitute an indirect pressure exerted sub silentio on the worker himself. Sec note 2 infra.

${ }^{2}$ Section $5(\mathrm{e})(\mathrm{I})$ of the Selective Service Act of 1940 authorizes the President by regulation to provide for the deferment of "those men whose employment in industry, agriculture, or other occupations or employment, or whose activity in other endeavors, is found . . . to be necessary to the maintenance of the national health, safety, or interest." Emphasis thus far has been upon the dependency deferment rather than upon the occupational deferment, dependency (Class III) bcing determined prior to occupational status (Classes II-A and II-B). Selective Serv. Reg. (2d ed.) \$623.2r. Herctofore, neither the individual's potential usefulness in other than his present employment nor the prospective need for his occupational skills appears to have been a pertinent consideration in applying the occupational deferment, except in the limited field where his current status (as unemployed or cngaged in nonessential work) is attributable to a "seasonal or temporary interruption." Selective Serv. Reg. (2d cd.) \$622.24; cf. Selective Serv. System Release No. 185, Fcb. 28, 1941. Bus. \& Depense Coondinston, p. 6,0II. Since all deferments are discretionary with the President and no order of application is prescribed in the law, the emphasis can readily be shifted to enable operation of the statute in a manner more conducive to effective labor mobilization. Public No. 625, 77th Cong., 2d Sess. (June 23, 1942), by providing dependents' allowances to men in military service, may facilitate such a shift. 'The recent Executive Order establishing the War Manpower Commission which vests broad powers in the Chairman to provide for the effective mobilization and maximum utilization of the nation's manpower, should lead to a more realistic allocation of manpower (on a qualitative basis) between the armed forces and essential civilian activities. Exce. Order No. 9139, April 18, 1942, 7 Fed. REO. 2919. War Manpower Commission Directive No. V, to the Director of Selective Service, clearly reflects such an approach. 7 FED. REG. 4749 (1942). A possible obstacle to centrally planned and executcd allocation is the seeming autonomy of the local boards of the Selective Service System in deferment detcrminations. Selective Service Act of 1940, $\$ 5(\mathrm{e})$.

It has been suggested that the pressure potentially exertable upon the individual in the form of threatened induction into military service might become the principal coercive force behind such measures of worker control as may be desired. Baruch, Taking tHe Profits OUT of War (1931) 34; 
involve specific directions by the Government to an individual to work at a designated task in a designated enterprise. Between the two extremes lie a multitude of measures and methods which may be applied progressively as the exigencies of current events require.

Since compulsory labor mobilization in our country ${ }^{3}$ will probably be progressive in character, this discussion of some of its legal aspects will be based on the progressive steps which may be taken. ${ }^{4}$ The alternative approach-to depict full and complete labor mobilization as it might appear in its final stage with a legal analysis of each detail-has been rejected because some of the steps discussed might not appear or might take different form, and because the ensuing conclusions which would then necessarily be based on the relation of each phase to the completed whole, might be misleading.

Effective utilization of the manpower of a nation necessarily entails, with respect to the individual worker, his placement and retention in that employment in which his capacities can be most effectively utilized in the national interest. Insofar as these objectives are accomplished by compulsion contrary to the individual's will, exerted either directly by the Government or indirectly by economic pressures governmentally inspired, certain peacetime rights of the individual are necessarily affected. These include the right to remain idle, ${ }^{5}$ the right to seek employment in whatever way desired, the right to choose one's employer and employment, and the right to bargain freely as to the terms of one's employment. These and other rights com-

Note, Mobilization for Defense (r940) 54 HARv. L. Rev. 278, 292. The limited effectiveness of a "Work or Fight" policy under the Selective Service Act of 1940 is apparent. Among its deficiencies are the non-liability for military service of women and of men in certain age groups, $\$ 3(a)$, the prohibition against deferment by occupational or industrial groups, $\S_{5}(\mathrm{e})$, the possible induction or voluntary enlistment in the armed forces of individuals with critical shortage skills required for essential war production, and the implication that service in the armed forces is a penalty for failure to serve more effectively elsewhere. The pertinence of First World War experience and thinking may also be doubted since thus far, at least, current labor shortages have been qualitative rather than quantitative. A "Work or Fight" policy is most effective in securing unskilled or semiskilled labor. Our present major problem involves the most effective utilization of workers possessing critical shortage skills, many of whom are already in war work. Of two individuals with identical employment, dependency and physical status, but differing in that only one possesses a critical shortage skill required for essential war production, it is doubtful whether $\$ 5$ (e) of the Act may be construed and applied to defer the less skilled individual and to induct the specially skilled individual who refuses to work where he is most urgently needed.

a For a summary of compulsory labor mobilization in other countries, see Hoague, Brown, and Marcus, Wartime Conscription and Control of Labor (1940) 54 HaRv. L. Rev. 50. For recent important developments in Canadian labor mobilization, see Nat. Selective Serv. Order of March 2I, I942 (P. C. 2250); Stabilization of Employment in Agriculture Regulations, March 2I, 1942 (P. C. 225I); Essential Work (Scientific and Technical Personnel) Regulations, 1942, March 4, 1942 (P. C. 638); and Order for Compulsory Registration of Unemployed Male Persons, May 19, 1942. Canada, Emergency Laws, Orders and Reg., pt. 37, pp. 27-41.

"We have frequently said that the legislative authority, exerted within its proper field, need not embrace all the evils within its reach. The Constitution does not forbid "cautious advance, step by step,' in dealing with the evils which are exhibited in activities within the range of legislative power." NLRB v. Jones and Laughlin Steel Corp., 30r U. S. I, 46 (1937).

E As to the right not to work, see 3 WILloughby, Constrmution of the UNIted States (1929) 51200; Keefer, Has a Person a Constitutional Right 10 Abstain from Work? (192r) 29 W. Va. L. Q. 20. Cf. ex parte Hudgins, 86 W. Va. 526, 103 S. E. 327 (1920); State v. McClure, 105 At. 712 (Del. 1919). 
monly enjoyed by individuals and frequently considered inviolate by the courts ${ }^{0}$ must be restricted in whole or in part if the primary objectives are to be secured.?

From the standpoint of the employer, the objectives of labor mobilization are corollaries of the above. The employer must facilitate the employment of the worker in that employment in which his capacities can be best utilized in the national interest and the expenditure in that employment of the worker's utmost effort. The employer likewise must surrender certain rights, for example, the right freely to solicit workers, the right to employ or not to employ, the right to fix the terms and conditions of employment, etc. Likewise, other persons or groups concerned in the relationship such as labor and employer organizations, employment agencies, ${ }^{8}$ and even state and local governments ${ }^{9}$ may be compelled to surrender rights to the extent that their exercise would interfere with the desired objectives.

The restriction of these rights might be accomplished in several ways. Three possible approaches suggest themselves. Labor mobilization might be accomplished in much the same manner and on the basis of the same principles as military conscription; all workers would be "conscripted"10 into a force resembling in objective and methods the organization now governing the armed forces of the nation. Inasmuch as the source of military law lies chiefly in historical precedent and in the express constitutional authority in the Congress, not only to raise armies but also to prescribe rules for the government and regulation of the armed forces, ${ }^{11}$ this method of achieving compulsory labor mobilization would undoubtedly meet constitutional difficulties. Although certain forms of military service approximate certain forms of service carried on by labor in civilian life, the power to govern and regulate the land and naval forces, in the course of which certain services may be required not of themselves military in character, differs materially from the power to declare war, to support armies and to maintain navies. ${ }^{12}$ Neither power may include the power to conscript and to govern, as an army is governed, the working forces of a nation. ${ }^{13}$

- Cf. Truax v. Raich, 239 U. S. 33 (I915); Coppage v. Kansas, 236 U. S. I (1915); Adair v. U. S., 208 U. S. x6I (1908); Allgeyer v. Louisiana, i65 U. S. 578 (1897); 2 Cooley, Constrtumonal LimirnTJONS (8th ed. 1927) I34I.

${ }^{7}$ Recent decisions of the Supreme Court have stressed the principle that all these sa-called rights or liberties are not immune to infringement by Congress or the States in the cxercise of constitutional powers. Olsen v. Nebraska, 313 U. S. 236 (1941); NLRB v. Jones and Laughlin Steel Corp., 301 U. S. I (1937); West Coast Hotel Co. v. Parrish, 300 U. S. 379 (1937). Adair v. U. S., 208 U. S. I6I (1908) and Coppage v. Kansas, 236 U. S. I (1915) have been "completely sapped * "of their authority." Phelps Dodge Corp. v. NLRB, 313 U. S. 177, 187 (1941).

${ }^{3}$ Cf. Olsen v. Nebraska, 313 U. S. 236 (1941).

${ }^{\circ}$ Cf. Oklahoma v. Atkinson, 313 U. S. 508 (1941); U. S. v. California, 297 U. S. 175 (1936); Wayne County v. U. S., 53 Ct. Cls. 417 (1918), affd, 252 U. S. 574 (1920). "Whenever the constitutional powers of the federal government and those of the state come into conflict, the latter must yield." Florida v. Mellon, 273 U. S. I2, 17 (1927).

${ }^{20}$ The word "conscription" is defined in Webster's New International Dictionary (2d ed.), as "a compulsory enrollment of men for military and naval service." Conseription of labor thus appropriately describes this approach but the term is misleading when used with rclation to other forms of labor mobilization not involving control equivalent or analogous to that exercised over the armed forces.

${ }^{21}$ U. S. Const., Art. $\mathrm{x}, \$ 8$, cis. 12 and 14.

${ }^{12}$ Id. Art. $\mathrm{I}, \$ 8$, cls. 11, 12 and 13; Selective Draft Law Cases, 245 U. S. 366 (1918).

${ }^{18}$ The conclusion might be different in instances of military government in which the military has 
A second possible approach to a compulsory labor mobilization program is direct operation by the Government of all essential war production enterprises. ${ }^{14}$ The power of the Government, during war time, to enter fields ordinarily occupied by private enterprise is beyond doubt. Instances during the past and present World War include the Government's operation of railroads, ${ }^{15}$ telegraph and telephone facilities, ${ }^{16}$ and airplane factories. ${ }^{17}$ If the Government replaces the private employer, many of the difficulties presented by the third approach discussed below would be removed. All doubts based on the distinction between services rendered directly for the Government and services rendered for private employers would be laid at rest. ${ }^{18}$ Assuming such replacement of private enterprise, the Government's power to accomplish all things necessary in the field of employment relations could not be seriously doubted. ${ }^{19}$

The third approach is that of increasing governmental control over all facets of the employment relationship by means of direct or indirect compulsions upon the various persons involved. It is of importance to recognize that the primary objective of labor mobilization, i.e., the placement of each individual worker in that position in which his capacities can be most efficiently utilized, can be achieved to a large degree by measures short of governmental compulsions operating directly upon the individual worker. If the individual is a wage-earner dependent upon employment for his livelihood-and this category would include the vast majority of potential workers in this country-his employment activities can be controlled to a large extent by controls upon the other party to the employment relationship, i.e., the employer. To the extent that the employment activities of employers are controlled directly or indirectly, corresponding activities on the part of employees are likewise controlled. The direction that is thereby given to the activities of the worker will depend not only upon the degree and nature of the control exercised but also upon the extent to which the controls apply to all employers. Obviously, if governmental control extends to only a portion of all employers in the nation, the worker will to that extent be

superseded a suspended sovereignty. Cf. Ex parte Milligan, 4 Wall. 2 (U. S. 1866); 3 WiLLOUGHBY, op. cit. stipra note $5, \$ 104 \mathrm{r}$ et seq. Of considerable interest in this connection are the measures of compulsory labor mobilization instituted by the Military Governor under the state of martial law now existing in Hawaii. These include the freezing of wages, regulation of hours on essential projects, and prohibitions against leaving essential employment. Wash. Post, April 5, 1942. For a discussion of the validity of other measures instituted in Hawaii, see Anthony, Martial Law in Hawaii (I942) 30 Caltf. L. REv. 37 r.

1t "Conseription of industry" has been widely discussed in connection with the "universal draft" principle. For a discussion of its constitutionality if unaccompanied by just compensation, see Cormack, The Universal Draft and Constitutional Limitations (1930) 3 So. CALIF. L. Rev. 361.

${ }^{25}$ Northern Pac. Ry. v. North Dakota, 250 U. S. I35 (I9r9).

${ }^{10}$ Dakota Central Tel. Co. v. South Dakota, 250 U. S. I63 (19r9).

${ }_{17}$ Occasions during the last and present war where entire enterprises were commandeered or simply "taken over" by the Federal Government are collected and discussed in Note, American Economic Mobilization (1942) 55 Harv. L. REv. 427, 518. In none of these were any measures of compulsory labor mobilization taken.

${ }^{18}$ See note 65 , infra.

10 U. S. Const., Art. I, \$8, cl. I8; cf. Hamilton v. Ky. Distilleries Co., 251 U. S. 146 (1919); Selective Draft Law Cases, 245 U. S. 366 (19r8). 
free to pursue his unrestricted employment activities with employers not within the purview of the Government's regulation. Employer control as contrasted with worker control offers for many reasons a more expedient approach to labor mobilization, at least in the early stages. Some of these reasons are discussed below.

The rights of employers in the employment relationship have undoubtedly come to be regarded as less sacred and inviolable than the corresponding rights of employees. In a certain sense, controls upon the exercise of these rights involve restrictions upon the employer's "liberty of contract," as contrasted with the more sacred personal rights of the worker. The employer enjoys the fruits of an individual's labor; the employer's activities are generally associated with the contractual side of the relationship rather than with the actual expenditure of personal service. ${ }^{2 n}$ Control of employers' employment activities has been frequently and widely exercised by both state and federal governments. Many precedents exist which justify such control from a constitutional standpoint. These precedents have arisen not only as a result of the exercise by the states of their police power ${ }^{21}$ but also are numerous in connection with the exercise by Congress of its interstate commerce, war, and other powers. $^{22}$

Wartime controls of the owners and producers of scarce materials and facilities are very closely analogous to controls over an employer's hiring and utilization of workers possessing shortage skills required for essential war production. Recent acts of Congress not only operate positively to require employers to fill Government orders or to give preference to orders of certain private persons, but also operate negatively to prohibit the sale or disposition of certain materials and facilities. ${ }^{23}$ Controls upon employers, necessary to secure the allocation and distribution of the labor supply essential for the maintenance of necessary civilian and war production activities, may entail much less drastic measures than those now in effect in connection with the allocation and distribution of essential materials and facilities. Another factor entitled to some weight is the fact that the employer's bargaining power is usually more

${ }^{20}$ Opposition raised by employers to laws regulating phases of the employment relationship has been based on liberty or freedom of contract rights. No case has been found in which the employer has interposed any defense analogous to that which the worker might raise under the Thirtecnth Amendment or on the ground of deprivation of personal liberty under the Fourteenth or Fifth Amendments. Cf. Marcus Brown Holding Co., Inc. v. Feldman, 256 U. S. 17o (1921).

${ }^{21}$ Manner of paying wages: McLean v. Arkansas, 211 U. S. 539 (rg09); Knoxville Iron Co. v. Harbison, 183 U. S. 13 (Ig0I). Hours of work: Bunting v. Oregon, 243 U. S. 426 (I9I7); Muller v. Oregon, 208 U. S. 412 (I908); Holden v. Hardy, I69 U. S. 366 (I898). Contract limfiting tort liability: Chicago, B. \& O. R. R. v. McGuire, 2r9 U. S. 549 (19rI). Employment of women: Radice v. New York, 264 U. S. 292 (1924). Cf. Mo. Pac. Ry. v. Mackey, 127 U. S. 205 (1888).

${ }_{22}^{2}$ U. S. v. Darby, 312 U. S. 100 (194I); NLRB v. Jones \& Laughlin Steel Co., 301 U. S. I (1937); Patterson v. Bark Endora, 190 U. S. 169 (1903). Cf. Second Employers' Liability Cases, 223 U. S. I (I912).

${ }_{23}$ The statutes and their administration are discussed in Note, American Economic Mobilization (1942) 50 Harv. L. Rrv. 427. See, for example, $\$ 2$ (a) of the Priorities Act, 54 Stat. 676 (1940) as amended, $4 \mathrm{r}$ U. S. C. (Supp. I) and $\$ 9$ of the Selective Service Act of 1940. Under these acts authority has been asserted and exercised to limit, restrict and prohibit certain types of production decmed unneces. sary and to regulate the use of certain scarce materials. Note, American Economic Mobilization, supra, at $455-465$. 
potent than that of the worker, ${ }^{24}$ with the result that considerable restriction of the employer's usual rights in the employment relationship may be accomplished without raising the worker to a preferred position. Finally, it is noteworthy that if employer controls result in substantial economic losses, such losses can be more effectively compensated by the Government. The employer can usually be made whole by money compensation if the payment of such compensation is necessary or expedient for constitutional or other reasons; deprivation resulting from regulation of the worker's rights in the employment relationship are not so readily compensated. ${ }^{25}$

From an administrative point of view, it is undoubtedly an easier task to regulate, directly or indirectly, employers than it is to enforce compulsory measures upon employees. Because employers are far less numerous than employees, greater coverage is achieved by application of the control to a few and the end to be accomplished entails substantially simpler policing. Again, the employer is usually more susceptible to indirect controls than is the employee; considerable influence upon an employer's hiring and employment practices might be exercised through his government contracts as well as through government controls of the raw materials, supplies and facilities without which the employer cannot continue his business. ${ }^{20}$

Although direct compulsion may be brought upon the employer without simultaneously bringing direct compulsion to bear upon the employee, in a practical sense the reverse is not true. If the role of the employer in the employment relationship is to control and supervise his employees, the manner in which that control and supervision is exercised is of paramount importance in the full utilization of an available labor supply. In fact, control of the employer is the only available means of securing desired results in certain parts of this field. The problems of labor conservation and of labor utilization cannot be met without controls upon the employer's activities in the employment process and relationship. ${ }^{27}$

If compulsory labor mobilization in our country proceeds by progressive steps, the first steps will probably involve the regulation and control of employers to the exclusion of direct controls upon workers. If and when employer controls fail to meet adequately the increasing labor demands of an expanding war economy, worker control will be the next resort. To the extent that the protection of workers and the achievement of the ends of worker control require, direct regulation of workers will entail new and additional restrictions upon the rights of employers.

The ensuing discussion can therefore be conveniently divided into ( $I$ ) measures of employer control, and (2) measures of worker and employer control.

34 Cf. Holden v. Hardy, x69 U. S. 366,397 (1898); West Coast Hotel Co. v. Parrish, 300 U. S. 379,393 (1937).

${ }_{25}$ Sce note 74 , infra.

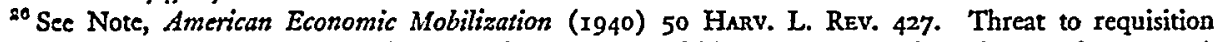
or commandeer, assuming the ultimate authority to requisition or commandeer, is not duress. $C f$. American Smelting Co. v. U. S., 259 U. S. 75 (1922); U. S. v. Tengey, 5 Pet. I15 (U. S. 1831).

${ }^{27}$ See pp. 447 et seq., infra. 


\section{r. Measures of Employer Control}

Three measures of employer control which undoubtedly will be given careful consideration when and if legislation in the field of compulsory labor mobilization is deemed necessary, are the following:

(a) Establishment of Labor Priorities and Control of the Hiring Process,

(b) Conservation of Critical Workers and Maximum Utilization of Labor Force,

(c) Displacement of Workers in Non-essential Activities.

(a) Establishment of Labor Priorities. Just as on the production side of the war effort, the initial stage in industrial mobilization was the establishment of a system of priorities or preferences whereby scarce raw materials or needed products and facilities were reserved for, and allocated to, essential war industries, so in labor mobilization the initial step will involve an allocation of the available "critical workers" (workers qualified to perform occupations required for essential war production, in which a serious labor shortage exists) to those employers whose need for such workers is most urgent from the standpoint of the national war supply program. ${ }^{28}$ While production priorities have long been obligatory by statute, labor priorities as of this date exist only as a policy of the United States Employment Service $^{29}$ in referring workers for employment.

\footnotetext{
${ }^{28}$ Under the priorities and allocation powers in $\$ 2(a)$ of the Priorities Act, supra note 23, as recently broadened and clarified by the Second War Powers Act, Pub. L. No. 507, 77th Cong., 2d Sess. (March 27, 1942), federal authorities have for some time regulated the use and procurement of scarce materials and products. See e.g., General Preference Order No. P-7, 6 FED. REc., 2875 (x941) (ship. builders); General Limit. Order L-2, id. 4735 (automobiles); Limitation Order L-7, id. 5534 (use of steel sefrigerators); Supplementary Order $M-I-c$, id. 2854 (aluminum serap); General Preference Order M-12, id. 4212 (cotton linters); General Metals Order No. 1, id. 2239; and General Preference Order M-I-A, id. 1599 (aluminum). See Weiner, Legal and Economic Problems of Civilian Supply (1942) 9 LAw \& CONTEMP. ProB. 122. The recently announced shift in priority procedures to one of following raw materials from their inception to the finished product, may result in the abandonment of some or all of the above illustrated types of control, but their usefulness as analogies for present purposes would not thereby be impaired.

${ }^{28}$ The Wagner-Peyser Act, 48 StAT. 113 (1933), 29 U. S. C. $\$ 49$, provided for a national system of public employment offices to be operated by the states under a system of grants-in-aid made (roughly) on a 50-50 basis. The various state unemployment insurance laws, enacted subsequently, required that benefits be paid solely through public employment offices. See, e.g., S. C. Unemployment Compensation Law, $\$ 3(a)$, S. C. Laws 1936, Act No. 946, and cf. Int. Rev. Code, \$1603(a)(1), 49 STAT. 640 (1935), 26 U. S. C. $\$ 1603$. This necessitated a great expansion in the public cmployment office system in each state, financed almost entirely by federal grants made to state unemployment insurance agencies under title III of the Social Security Act, 49 STAT. 626 (I935), 42 U. S. C. \$502. On January I, I942, operation of a national system of public employment offices was undertaken by the Social Security Board pursuant to the President's direction and determination that the national war effort required a single, nationally-directed system of public employment offices. Funds for their administration were made available in the Labor-Federal Security Appropriation Act for the fiscal year ending June 30, 1942, Pub. L. No. 146, 77th Cong., Ist Sess (July I, 1941). State governments cooperated in establishing the national system by releasing personnel and facilities, used in their respective state offices, to the Social Security Board. The federally-operated system is now known as the "United States Employment Service" and is in the Social Security Board. The Board is under the "supervision and direction" of the Federal Security Administrator, Reorganization Plan No. I, \$201, effective July I, 1939, 4 FED. REG. 2728, 53 STAT. 1424, 5 U. S. C., \$133. Paul V. MeNutt, the Federal Sccurity Administrator, is also Chairman of the War Manpower Commission. Exec. Order No. 9139, 7 FED. REc. 2919 (1942).
} 
The United States Employment Service has been filling employers' orders for workers in accordance with a schedule of priorities roughly based on preferences established for the war production program. ${ }^{30}$ Of several employers seeking critical shortage workers through the United States Employment Service, preference is given to the order of that employer whose production is most essential to the war effort. To the extent that employers are dependent for their labor supply upon the United States Employment Service, the policies observed by the United States Employment Service in filling employer orders determine the allocations made of available workers. On the other hand, as long as employers retain and exercise the privilege of recruiting workers directly or through employment agencies other than the United States Employment Service, the priorities established by the United States Employment Service are not only ineffective to accomplish the desired result, but employers having low, or no, preference ratings are in practical effect induced not to use the public employment office and to compete with such offices in the open labor market. Uncontrolled competition for critical workers between non-war and war employers impedes the desired shift of such workers from non-war to war production, while uncontrolled competition among war production employers contributes greatly to needless and wasteful labor turnover and labor unrest.

Governmental control of hirings, possibly restricted to occupations required for essential war production in which a shortage of qualified workers exists, is therefore a reasonable initial step in a labor mobilization program. Its twofold purpose being to insure an adequate supply of workers for essential war industry by enforcement of priorities and to prevent labor unrest and consequent labor waste by reducing the inducements to labor turnover, precedents supporting Government-controlled allocation of necessary raw materials, supplies and facilities and for prevention of waste of scarce materials and facilities are clearly in point. ${ }^{31}$ That the public has a legitimate - interest in hiring activities apart from the exercise of war powers is attested by numerous laws regulating private employment agencies, ${ }^{32}$ and by laws, both state and federal, for the creation and maintenance of public employment offices. Such government control may take the form of $(\mathrm{I})$ requiring all hirings for critical occupa(1942).

${ }^{80}$ See War Manpower Commission Directive No. III, to U. S. Employment Service, 7 Fed. Reg. 4748

\$2 For the scope of the war power see the famous dicta of Brandeis, J., in U. S. v. McIntosh, 283 U. S. 605, 622 (I93I), and Hughes, C. J., in Home Building and Loan Ass'n v. Blaisdell, 290 U. S. 398,426 (1934). The constitutionality of an allocation system was apparently assumed in Atwater \& Co. v. U. S., 275 U. S. 188 (1927) and Omnia Commercial Co. v. U. S., 26I U. S. 502 (1923), and was upheld specifically in Roxford Knitting Mills v. Moore \& Tierney, Inc., 265 Fed. 177 (C. C. A. 2d, 1919) cert. denied, 253 U. S. 498 (1920). Conservation, and its apposite, prevention of waste, are clearly proper subjects for governmental concern and control, either as measures of facilitating allocation or as measures of allocation itself. See Note, American Economic Mobilization (1942) 55 Harv. L. Rev. 427,463 (1942). Measures for prevention of waste of national or state resources have been upheld independently of the war powers. Cf. Champlin Refining Co. v. Corp. Comm. of Oklahoma, 286 U. S. 210 (1932). See note 45 infra. No valid distinction can exist insofar as the employer is concerned between the allocation of scarce materials and facilities needed in the war effort and the allocation of scarce labor, the purposes of both measures and their relation to the war effort being identical.

${ }^{92}$ Olsen v. Nebraska, 313 U. S. 236 (194I); Brazee v. Michigan, 241 U. S. $34^{\circ}$ (1916); Brandeis, J., dissenting in Adams v. Tanner, 244 U. S. 590, 597 (I917). 
tions to be carried on through public employment offices or subject to their control, and (2) regulating or prohibiting all forms of public or private solicitation of critical workers. The prohibition or regulation of solicitation is necessary both to prevent labor waste, and as an incidental measure reasonably appropriate to the enforcement of exclusive hiring controls. ${ }^{33}$

Experience during the current war seems to indicate that national labor shortages develop largely in a few occupations requiring a high degree of skill and a correspondingly long period of experience and training. Government regulation will normally, then, be directed at these occupations. Enabling legislation is not likely to attempt detailed specifications as to the occupations affected. New shortages of skilled workers in critical occupations will develop, and former shortages may disappear from time to time in the normal metamorphosis of the war production program; unforeseeable shifts in emphasis are inevitable in the war supply program, while the demands of the armed forces are unpredictable both as to number and type of men needed. The immobility of labor will give rise to shortages in some areas while in other areas the supply of qualified workers may be adequate or even in excess of local needs. Hence, the likelihood of a general definition of critical occupations and a delegation of authority to an administrative agency to specify the occupations to which, and the localities in which, the controls will be applied. ${ }^{34}$

The control may be directed either at the qualifications of the individual hired, or at the work for which the individual is hired. The first approach appears more direct and if feasible, more effective; it would involve, however, knowledge on the part of the employer of the qualifications of each worker he proposes to hire, facts peculiarly within the knowledge of the worker. Since it would be unreasonable to charge an employer with the truth and accuracy of facts supplied to him by a worker, ${ }^{35}$ the first approach would require some predetermination by the Government of each worker's qualifications, and communication of such information to prospective employers. Each worker might be furnished with a card upon which his qualifications (or lack of qualifications) are noted, and each employer thereby charged with knowledge of the qualifications shown on the card, to be produced by the worker as a condition precedent to a hiring. ${ }^{36}$

\footnotetext{
${ }^{83}$ It is of interest to note that the "regulation" promulgated by the Director of the United States Employment Service during the First World War undertook not only to require that certain cnterprises hire only through public employment offices but also to restrict solicitation and advertising for labor. Hoague, Brown \& Marcus, supra note 3, at 57. Control of advertising marked the first hesitant otep in both English and Canadian labor mobilization programs. Cf. Control of Employment (Advertiscments) Order, 1940, S. R. \& O. 1940, No. 522, BuRke, WAR Legislation [Eng.] (1940) Go5; Labor Enticement Regulations, Nov. 7, 1940 (P. C. 6280), Canada, Emergency Laws, Orders, and Reg., pt. 37, p. 15. Canada has recently instituted control of hiring. Control of Employment Regulations, 1942, June 12, 1942 (P. C. 5038 ), id. pt. 37 , p. 27.

3s Reasonable delegations of this type are beyond question. Cf. Opp Cotton Mills, Inc. v. Administrator, 312 U. S. 126 (194I); Sunshine Coal Co. v. Adkins, 310 U. S. 381 (1940).

ss War does not waive the necessity for due process, one of the requirements of which is the fixing of an ascertainable standard of guilt. U. S. v. Cohen Grocery Co., 255 U. S. 81 (rg2I).

${ }^{80}$ Obviously such a system would require a card for every potential worker, whether or not qualified in the critical occupations. Otherwise failure to produce a card could be attributed either to concealment by the qualified worker or to an actual lack of qualification. To police the regulation, probably
} 
Assuming controls applicable solely or primarily to employers, the second approach is more feasible. The type of work for which a worker is hired is a fact, knowledge of which is reasonably chargeable to the hiring employer. The only legal objections that an employer might raise to a law imposing penal sanctions for his failure to hire persons for specified critical occupations in accordance with prescribed methods, would be that the restricted occupations were not susceptible of definition with sufficient precision to charge him with notice that the particular job for which he hired a worker fell within the prohibited class. The occupations likely to be so restricted are generally susceptible of descriptions sufficiently precise to meet any such objection; ${ }^{\mathbf{3 7}}$ such an objection loses all force if the employer is afforded adequate opportunity to obtain clarification from an administrative agency such as the public employment offices, or may protect himself by hiring exclusively in accordance with the methods prescribed for the restricted occupations, or both.

(b) Conservation of Critical Workers and Maximum Utilization of Skills. Establishment and enforcement of labor priorities, with control of hiring as the modus operandi, leaves the currently employed largely untouched. But just as in the production field the exigencies of modern war have necessitated governmental control of inventories and surplus stocks of scarce materials, ${ }^{38}$ so in the labor field it is improbable that employers would long be left entirely to their own devices in their utilization, or waste, of the skills of their current labor force. Government has already interested itself in the manner in which employers utilize workers in their employ. Much has been accomplished on a voluntary basis; particularly in cases in which Government and employer interests coincide, voluntary cooperation may be expected to continue to play a leading role. ${ }^{39}$ But as new shortages develop and old shortages become more critical, hoarding or wasteful utilization of workers possessing critical skills by uncooperative employers will become intolerable and direct controls in this field may be expected.

The term labor conservation, when used with reference to critical workers, embraces, positively, the employment of a critical worker exclusively at operations fully utilizing his special skill, and negatively the release of a critical worker from employment in which his skill is not, or cannot be, fully utilized. A critical worker may be employed to perform tasks, none of which involve an exercise of his special skill;

the card would have to be retained by the employer while the worker was in his employ. So long as there is no general labor shortage and critical occupations remain relatively few, the labeling of every worker and the consequent inconvenience to those with whose employment the Government is not concerned, would hardly be justified. Innocent loss of a card or its unjustified retention by an employer may cause hardship to a worker thereby precluded from employment until the lost card is replaced or returned to him. Analogous "leaving certificates" caused such a furor in England during the last war as to lead to their abandonment in October, 191\%. Hoague, Brown, and Marcus, Wartime Conscription and Control of Labor (r940) 54 HARv L. Rev. 50, 68.

${ }^{32}$ An ambitious effort to catalogue and define occupations resulted in the "Dictionary of Occupational Titles" (1939), prepared by the U. S. Employment Service when a bureau in the Department of Labor. It is available to public purchasers through the Government Printing Office.

${ }^{38}$ See Note, American Economic Mobilization (1942) 55 HARv. L. Rev. 427, 455 et seq.

${ }^{30}$ See Business \& Defense Coordinator, Fighting Labor Scarcity, C-3, 701 et seq. 
labor conservation in such a case would either require that the worker be released or employed at an operation or operations in which his skill will be fully utilized. A critical worker may be employed partly at operations involving an exercise of his special skill and partly at other severable operations; labor conservation in such a case would require that the operations be segregated (a process known as "job simplification") and the critical worker employed exclusively at operations which require the exercise of his special skill. If an employer is unable or unwilling to offer a critical worker full-time employment at operations involving exclusively the exercise of his special skills, labor conservation may require that the worker be released and made available to other employers who can and will afford such full-time employment.

Obviously, labor waste is not peculiar to employers engaged in war production; it may occur wherever critical workers are employed. Controls in this field may therefore apply to all employers alike, the line being drawn not on the basis of the occupations or operations in which an employer utilizes a worker, but on the basis of the qualifications of the workers he employs. Labor waste may be committed by an employer quite unknowingly, while measures of labor conservation, involving a high degree of technical knowledge both of machines and men, may be beyond the employer's ability to conceive and initiate. Government controls in this field may therefore be applied through directives or orders issued to the particular employer, setting forth in reasonable detail the respects in which the employer is wasting critical labor. If the employer can offer no work at which the skill of the critical worker could be fully utilized, his release may be ordered. If, on the other hand, the employer's activities include operations at which a critical worker could be fully utilized, the employer would presumably be given the choice of fully utilizing the worker's skill, or of releasing the worker.

Closely akin to conservation of critical workers and in many instances inseparable in actual practice from it, is the problem of maximum utilization of an employer's available labor force. Maximum utilization includes not only the full utilization of critical workers, but also the utilization of semi-skilled or unskilled workers in the performance of work for which critical workers would be preferred if available.

The interest of Government in the maximum utilization of critical and noncritical workers differs substantially from its interests in the conservation of critical labor. Its interests in the latter arise primarily out of the shortage of critical workers and the necessity that as many as possible be made available for war production; the employer's choice is either to utilize fully or to release the worker. The Government's interest in the maximum utilization of all workers arises out of, and is coextensive with its interest in, the continued production, notwithstanding labor shortages, of business enterprises. The Government is vitally and legitimately interested in maximum production by private enterprises producing materials or providing facilities required in the prosecution of the war. Its interest in the continuation of private enterprises not engaged in war production is not so apparent. In either case, 
shortages of critical workers may result in the dependence of an enterprise upon the effectiveness with which management practices conservation in its use of critical labor and utilizes the services of non-critical workers to perform tasks for which only non-critical workers are available.

The Government's interest in the continued welfare of private enterprises, whether or not engaged in war production, is sufficient to warrant an exercise of its spending power to lend reasonable technical aid where requested and needed. Maximum production by private enterprises engaged in war production is of sufficient public concern to warrant such control of management as may be required to insure against avoidable stoppage or impairment of production levels. Whether the interest of the Government in the continuance of non-essential private enterprises warrants compulsory measures against the will of the enterprise itself is doubtful. The problem becomes largely academic in view of the fact that in this field public and private interests largely coincide, and the fact that the limited number of persons technically qualified for such work will require that their full attention be devoted to enterprises engaged in essential war production. The difficulty of differentiating in a statute between employers engaged in essential war production and those not so engaged, may justify a failure to make the distinction in the enabling act. ${ }^{40}$

The principal available measures to effectuate labor conservation and prevent labor waste are job simplification, discharge and upgrading. Corresponding measures to promote maximum utilization of an existing labor force are job simplification, upgrading and training. Discharge of unutilized workers requires no explanation. Its direct relation to labor conservation is apparent since retention by an employer of a critical worker whose skills the employer cannot or will not utilize constitutes the extreme example of labor waste. The impact of this measure upon the employer, though drastic, is simple and direct. The employer has no absolute right to the worker's services and the worker has no absolute right to continue in the employer's employ; though the broken employment contract may have been most valuable to both and the resulting losses severe, since the Government has asserted no right under the contract of employment, no infringement of rights guaranteed by the Fifth Amendment is involved.11

\footnotetext{
${ }^{10}$ See note 59 infra. If the enforcement is by directives or orders, an employer engaged in war production against whom the Government seeks to enforce the statute would not be heard to complain on the grounds that the statute as applied to others might be unconstitutional. I WiLLovgrBy, CoNsmiution of the UNITEd States, r9; I Cooley, Constitutional Limitations (8th ed.) 399.

${ }^{41}$ Cf. Omnia Commercial Co., Inc. v. U. S., 261 U. S. 502 (1923), in which the Court said that "the essence of every executory contract is the obligation which the law imposes upon the parties to perform it," and that a governmental requisition of the entire product of a steel plant did not purport to be, or effect, a taking of a contract under which the steel company had contracted to deliver steel to a third person, nor a taking of the third party's right to demand performance, but merely operated to end the contract. Id. 510. Cited with approval was Marshall v. Glanvill, [19I7] 2 K. B. 87 , to the effect that a contract of employment is made on the assumption that performance will continue to be lawful and that the contract comes to an end when the rendition and acceptance of the services becomes unlawful. Id. $51 x$. Upon similar reasoning the worker would be without remedy. Highland v. Rursell Car \& Snow Plow Co., 279 U. S. 253 (1929). Cf. Duckett \& Co. v. U. S., 266 U. S. I49 (1924), and Int. Paper Co. v. U. S., 282 U. S. 399 (1931), involving, respectively, leasehold and water rights which were themselves the subject of a requisition.
} 
Job simplification involves the breaking down or segregation of a complex operation previously performed by one worker of high skill into several operations, one or more of which is capable of being performed by workers of lesser skill. Its pertinence both to labor conservation and to maximum utilization is apparent; in the process a critical worker is released from operations not requiring the full exercise of his skill, while at the same time all or part of a complex operation is performed by non-critical workers, an adequate supply of whom presumedly exists. Job simplification is a technical and complex process requiring expert knowyledge, a process well within the traditional province of management. Such being its nature, controversy is inevitable not only as to the need for job simplification in a particular case, but also as to the method of its accomplishment.

Upgrading involves the employment of a worker in that operation in which his skill can be most effectively utilized, the choice of operations being based largely upon the available supply of labor. This measure is inextricably bound up with job simplification and training, the former decreasing the degree of skill required and the latter making possible the acquisition of such skill as is required. In its legal aspects, upgrading differs little from job simplification.

Training in a limited form is properly a measure of maximum utilization; it constitutes a labor conservation measure only if failure to develop potential skills constitutes a form of labor waste. As used in this discussion, the term "training" includes all training and instruction afforded by an employer as an incident to the full utilization of his workers for his own needs. If incidental to upgrading, training must be justified as a proper subject of Government regulation and control upon the same theory as upgrading is justified, and presumedly would have the same legal implications. Training provided by an employer in order to meet the needs of other employers, or to increase the general labor supply, is not within the purview of a maximum utilization program. If the purpose and nature of a training program bears no relation to the increased efficiency or production of the employer required to provide particular training, such training would probably be required under principles analogous to those of eminent domain, ${ }^{42}$ and appropriate compensation provided.

Assuming that the need for governmental intervention can be demonstrated and that the method of its exercise is reasonable, little doubt exists that the war powers of Congress authorize the measures of control over private enterprise contemplated in labor conservation and maximum utilization programs. ${ }^{43}$ Labor conservation in the

\footnotetext{
12 That the power of eminent domain extends to a taking which in its immediate result benefits another person, has often been recognized. A use is no less a public use because private persons are the immediate beneficiaries. This, of course, is as true in the case of eminent domain as in the case of the police power. Strickley v. Highland Bay Mining Co., 200 U. S. 527 (1906); Clark v. Nash, 198 U. S. $36 \mathrm{I}$ (1905). Cf. Miller v. Schoene, 276 U. S. 272 (1928). Compulsory training of worlscrs either for the labor needs of a particular employer (other than the training employer) or for the general betterment of the labor market would probably constitute a taking for a public use and as such require just compensation under the Fifth Amendment. Cf. Pennsylvania Coal Co. v. Mahon, 260 U. S. 393 (I922).
}

43 "But there can be no doubt that upon proper occasion and by appropriate measures the State 
sense here used has precedents in measures taken during the preceding and the current war for the conservation of scarce materials, facilities and commodities essential to the war effort; wartime conservation in other fields has been obscured by indirection of method, but similarity in purpose exists notwithstanding the dissimilarity of approach. ${ }^{44}$ Waste itself has long been a matter of public concern and a proper subject of Government control. Waste in itself, however innocent, may constitute an evil which is subject to Government prohibition. ${ }^{45}$

In considering the validity of compulsory measures designed to insure maximum utilization of a labor force, the most difficult case is presented if no reliance is placed upon the respects in which maximum utilization aids in the prevention of labor waste or upon the principles citable in support of waste prevention. Assuming that waste of potential skills is a proper subject of governmental restraint, the appropriate remedy for waste, i.e., release of the potentially skilled worker, would not promote the objectives of maximum utilization. The primary object of the Government in a maximum utilization program is not to prevent labor waste as an end in itself but to insure the continued and maximum productivity of a particular plant or enterprise, notwithstanding a labor shortage.

It is assumed that compulsory measures to effect maximum utilization of a labor force will in practice be the Government's last resort, taken only after all measures to secure voluntary cooperation have been exhausted and only when the emergency is great. The validity of such compulsory measures may therefore be considered as applied to a recalcitrant employer whose continued and maximum production is vitally necessary to the supply of the armed forces or the maintenance of essential civilian needs. Unless such employer fully utilizes his present labor force, prevailing scarcities of critical workers are such that his essential production must either be seriously curtailed or maintained by sacrificing the essential production of other

may regulate a business in any of its aspects." Nebbia v. New York, 291 U. S. 502, 537 (I934). If this principle applies to regulations under the police power under the Fourteenth Amendment, the Fifth Amendment cannot impose a greater limitation on the war powers of Congress. Hamilton v. Kentucky Distilleries, 25 I U. S. 146 (1919).

"That one of the primary purposes of the Lever Act of the First World War, 40 STAT. 277 (I9I7), was to prevent waste and hoarding was acknowledged in several Supreme Court cases without question as to the legitimacy of the purpose. See, e.g., Highland v. Russell Car and Snow Plow Co., 279 U. S. 253, 259 (1929); and see U. S. v. Penn. Central Coal Co., 256 Fed. 703, 705 (D. Pa. I918), in which the court said "when a state of war exists, the whole nation is pledged to its successful prosecution. Its resources must be controlled and preserved, that large armies may be maintained in the field." Prevention of hoarding is mentioned as one of the purposes of the Emergency Price Control Act of 1942, Pub. L. No. 421, 77th Cong., 2d Sess. (Jan. 30, 1942).

"S That the state has a legitimate interest in conserving its natural resources which it can protect by regulatory and prohibitory laws is strikingly illustrated by statutes directed at conserving oil and natural gas. Not only have purely wasteful measures of production been prevented, Ohio Oil Co. v. Indiana, 177 U. S. 190 (1900), but the use of natural gas for certain nonessential purposes has been prohibited. Wells v. Midland Carbon Co., 254 U. S. 300 (I920); Henderson Co. v. Thompson, 300 U. S. 258 (1937); see Ely, The Conservation of Oil (1938) 51 Harv. L. REv. 1209; Moses, Constitutional, Legislative and Judicial Growth of Oil and Gas Conservation (I941) I3 Miss. L. J. 353. A similar public interest in the conservation of its manpower was recognized in Mountain Timber Co. v. Washington, 243 U. S. 219 (19I7). Cf. Barbier v. Connolly, I13 U. S. 27 (1885). In time of war a nation's manpower is undoubtedly its most precious and most limited natural resource. 
employers from whom critical labor will be diverted. The public interest in such an employer's enterprise far transcends the public interest asserted during peacetime in public utilities or in other forms of private enterprise subjected to equally drastic measures of control. ${ }^{46}$ The interest of Government in the continued and maximum production of essential war industries is beyond dispute; it is a legitimate interest and one which the Government may and does ofttimes subserve by itself undertaking the performance of the same functions. The need for Government interference to insure continued production will presumedly be demonstrable factually in terms of the existence of a labor shortage, of the effect of that shortage upon the maintenance of the employer's production levels and of the importance of continued production to the continued existence of the sovereign itself. The controls involved will be regulations of the employer's use of his labor force. The utilization of one's labor force is not more sacrosanct than the price one may demand for his product, the wages he pays his workers, or any of the innumerable incidents to the use of property and labor which have been held subject to the police power of the states, or analogous powers of the Federal Government. ${ }^{47}$

The employer will, of course, not be required to continue his business; he may abandon it at any time. ${ }^{48}$ But so long as he continues to produce materials or provide

\footnotetext{
"Consider, for example, the businesses "affected with a public interest," applying the quoted phrase in the sense used in Olsen v. Nebraska, 313 U. S. 236 (I94I), rather than Ribnic v. McBride, 277 U. S. 350 ( 1928 ). While the analogy to public utilities is helpful as indicating the legitimacy of governmental concern in, and control of, war production cnterprises, reservation must be made as to the incidents of that control; thus assurance of a "fair recurn" would not secm necessary. Scc note 48 infru. It is interesting to note that oil and gas conservation measures have been accomplished without de. pendence upon the public utility concept. Cf. Williams v. Standard Oil Co. of Louisiana, 278 U. S. 235 (rg29).

17 Any attack would probably be based on the due process clause of the Fifth Amendment. But the test of due process is reasonableness of relation to the end sought to be achieved. The controls would be unconstitutional under the Fifth Amendment "only if arbitrary, discriminatory, or demonstrably irrelevant to the policy the legislature is free to adopt, and hence an unnecessary and unwarranted interference with individual liberty." Nebbia v. New York, 291 U. S. 502, 539 (1934). The war powers of Congress, like the interstate commerce power, are at least equivalent to the police power of the states. Hamilton v. Kentucky Distilleries Co., 25 I U. S. 146 (rgrg); U. S. v. Rock Royal Cooperative Co., 307 U. S. 533 (1939). As to the extent of the war powers, see Miller v. U. S., II Wall. 493 (I87I); Ex parte Milligan, 4 Wall. 2 (U. S. 1866); Northern Pac. Ry. v. North Dakota, 250 U. S. 135 (1910). So tremendous is the war power that the test for due process may be not the presence of reasonableness but the absence of arbitrariness; the criterion expressed in Hamilton v. Kentucky Distillerics Co., supra, at $16_{3}$, was that "its action, unless purely arbitrary, must be accepted and given full effect by the Courts." Cf. U. S. v. Chemical Foundation, 272 U. S. I (1926); Schenck v. U. S., 249 U. S. 47 (Igr9); see U. S. v. MacIntosh, 283 U. S. 605, 622 (r93I); Home Building \& Loan Ass'n v. Blaisclell, 209 U. S. 398, 426 (1934). A discussion of the war powers is contained in Hearings before the Hotuse Committee on Banking and Currency on H. R. 5479, stiperseded by H. R. 599o, Price Control Bill, 77th Cong., ist Sess. (r94I), pt. I, 63 et seq.

${ }^{8}$ On this basis the public utility cases may be distinguished to the extent that their regulation may depend upon the power of eminent domain and be subject to the rule of fair return. Smyth v. Ames, 169 U. S. 466 (1898). The "privilege" of discontinuing one's business has often been relied on as an answer to the contention that one is deprived of property without due process if not assured a fair return under governmental regulations and control. Cf. Munn v. Illinois, 94 U. S. I13 (1876); Du Pont $d$ : Nemours \& Co. v. Hughes, 50 F. (2d) 82 I (C. C. A. 3d, r93I). Even as respects public utility cases the rule of fair return does not justify unreasonable rates notwithstanding such rates being the only alternativc. Public Service Comm'n v. Great Northern Utilities Co., 289 U. S. 130 (1933). The riglit to fo out of business may be circumseribed by governmental regulation in time of emergency. "The power to
} 
facilities, in the continued production of which the public has a legitimate interest, he will be required to comply with whatever reasonable regulation the Government finds necessary to protect its interest. Any losses which occur by reason of his compliance with such regulation, being losses attributable to a regulation of use required in the public interest rather than a direct appropriation, will not constitute a "taking" of private property within the meaning of the Fifth Amendment, requiring just compensation. ${ }^{49}$ Indeed, since the public interest and the employer's own interest largely coincide, it would be difficult if not impossible to ascribe the costs of protecting the interest to anyone other than the employer. ${ }^{50}$

(c) Displacement of Critical Workers from Nonessential Work. Assuming a progressive tightening of the labor market due to the rapid expansion of the war production program and the simultaneous withdrawal for the armed forces of many would-be workers, it is not unlikely that the measures discussed above will prove insufficient to meet the labor needs of essential war industries. Circumstances may be such as to warrant compulsory discharge of workers from nonessential enterprises, unaccompanied by the compulsory transfer of the displaced worker to essential war industry. Such compulsion would operate exclusively upon the employer, the subsequent employment or unemployment of the worker being left to the worker himself, except insofar as employer controls, such as control of hiring processes, will restrict the worker's choice of positions and in all probability lead to his employment where most urgently needed in the war effort.

go out of business when it exists, is an illusory answer to gas companies and water works, but one need not stop at that. The regulation is put and justified as a temporary measure. . . A A limit in time, to tide over a passing trouble, well may justify a law that could not be upheld as a permanent change." Block v. Hirsh, 256 U. S. 135, 157 (I921).

"Whether the type of legislation here considered would violate the "just compensation" provision in the Fifth Amendment, would depend upon whether there is a "taking" of private property. That clause is described in the Legal Tender Cases, 12 Wall. 457, 551 (U. S. 1871), "as referring only to a direct appropriation, and not to consequential injuries resulting from the excreise of lawful power. It has never been supposed to have any bearing upon, or to inhibit laws that indirectly work harm and loss to individuals." See Hearings, supra note 47 , at 302 et seq. Thus price fixing and allocation during the last World War, when unaccompanied by an actual requisition of the product, the price and disposition of which were minutely regulated, were held not to constitute a "taking" within the Fifth Amendment. Morrisdale Coal Co. v. U. S., 259 U. S. I 88 (1922); American Smelting Co. v. U. S., 259 U. S. 74 (1922); Omnia Commercial Co., Inc. v. U. S., 26r U. S. 502 (r923); Du Pont de Nemours \& Co. v. Hughes, 50 F. (2d) 821 (C. C. A. 3d, r93I). The dictum tending to the contrary in Matthew Addy Co. v. U. S., 264 U. S. 239, 245 (1924), has not crystallized into law. Regulation of the use of labor, including compulsory training, may increase the cost of doing business; as such it is more analogous to minimum price fixing than to maximum price fixing. $C f$. Hegeman Farms Corp. v. Baldwin, 293 U. S. 163 (1934). More exact analogies are found in wage and hour laws, and laws governing labor relations, workmen's compensation and unemployment insurance. All of these laws increased the costs of doing business, but none provided for compensation or assured a fair return, U. S. v. Darby, 312 U. S. 100 (194I); Mountain Lumber Co. v. Washington, 243 U. S. 219 (1917); NLRB v. Jones \& Laughlin Steel Corp., 30r U. S. I (1937); Carmichael v. Southern Coal \& Coke Co., 30r U.S. 495 (1937).

${ }^{60}$ Incidental hardship in particular cases does not suffice to render an otherwise reasonable regulation unconstitutional. N. Y. Rapid Transit Corp. v. City of New York, 303 U. S. 573 (1938); Bayside Fish Co. v. Gentry, 297 U. S. 422 (1936). And the fact that the loss due to the regulation might be such as to put marginal competitors out of business does not of itself indicate unreasonableness. Opp Cotton Mills, Inc. v. Administrator, 312 U. S. 100 (I94I); Hegeman Farms Corp. v. Baldwin, 293 U. S. 163 (1934). 
Such restriction or prohibition upon an employer's right to enjoy the benefits of an existing employment relationship has a direct analogy in wartime restriction on the use of property and facilities required for the war effort. The employer's right to the continued employment of a worker is at best equivalent to the right of a party to an executory contract to demand performance; the Thirteenth Amendment would preclude the assertion of a greater right.51 As such, the employer's interests are no less immune to governmental deprivation than is the right of a contractor to performance of a contract, performance of which is prohibited or rendered impossible by the Government. There would, of course, be no occasion for compensation under the Fifth Amendment. ${ }^{62}$

The validity of such enabling legislation is largely dependent upon the manner in which the governmental control is to be exercised. Compulsory measures of this character are peculiarly susceptible to abuse, in that application of the controls may result in unfair discrimination between employers of critical workers. While the indirectness of the fundamental method is not in itself objectionable, the dissimilarity between the end (i.e., to meet the labor needs of war industries) and the method (i.e., to require non-essential employers to discharge critical workers), renders it difficult to arrive at a modus operandi that will adequately subserve the purpose while fully protecting employers against arbitrary and unreasonable discrimination. The legislator's problem is further complicated by the fact that under these as well as other measures discussed, the worker himself must be protected-a fact that sharply differentiates this type of action from its counterpart in the control of materials and facilities.

A possible approach is the classification of business enterprises normally employing critical workers in the order of their contribution to the war effort, employers employing critical workers in enterprises at the bottom of the list being subject to first call for the release of all or a certain proportion of their critical workers as the needs of the war production program require. The classification of business enterprises, the determination of the type and number of workers required for war production purposes, the designation of the enterprises which must release workers, and the determination of the number or proportion which each must release, in order to make available the number of workers required for war production purposes,

${ }^{52}$ Clyatt v. U. S., 197 U. S. 207 (1905).

${ }^{53}$ Continued employment of certain critical workers under the circumstances here considered has become detrimental to the public interest. That which may be regulated may be prohibited altogether, if prohibition is reasonably necessary to effect the legitimate ends of Government. Powell v. Pennsylvania, 127 U. S. 678 (1888). No taking of property under the Fifth Amendment is involved since the effect of the prohibition is to end the contract of employment, not to appropriate it. Cf. Omnia Commercial Co. v. U. S., 26I U. S. 502 (I923); Hamilton v. Kentucky Distilleries, 25I U. S. I46 (1919); and cases cited in note 49 stspra. Perhaps the closest analogies in the field of priority and allocation control are found in the General Limitation Orders of the OPM and WPB which prohibit the production of certain nonessential articles requiring needed raw materials and facilities or prohibit the use of scarce materials in the production of such articles. See Weiner, Legal and Economic Problems of Civilian Supply (1942) 9 LAw \& CONTEMP. Prob., 122, 132 et seq. The indirection of this type of order is of special interest in this connection. "Damage to the worker would be incidental and within the rule of the Legal Tender Cases, 12 Wall. 457,551 (U. S. 1870). 
would be left to the administrative agency. Refinements reasonably related to the purposes, such as designation by locality rather than nationally, and special dispensation for hardships either to employers or workers, or both, would not present legal obstacles. ${ }^{53}$ Objections based on the unreasonableness or arbitrariness of the classification would not be applicable under such an approach, and helpful analogies are available in other forms of wartime Government controls. ${ }^{54}$

Under any approach the selection, as between two or more employers in substantially the same circumstances so far as their need for their critical workers and their lack of relation to the war effort is concerned, could reasonably be made on the basis of the likelihood of placing the displaced workers in war industry, including such considerations as the willingness and availability of the worker himself. The standards to govern the selection of workers to be displaced under this type of measure will entail greater difficulties than any measure heretofore considered, but if the standards selected are consistent with the purpose to be subserved and are sufficiently precise to insure against unreasonable and discriminatory treatment of employers and workers, no valid legal objection could be made. ${ }^{55}$

\section{Measures of Worker and Employer Control}

The measures thus far discussed have involved exclusively controls or regulations applicable solely to employers. ${ }^{56}$ Control or regulation of the other party to the employment relationship, the worker, is logically the next step. Up to this point, it has been assumed that measures of employer control will be tried before the Government embarks upon the next step. However, it is equally possible that measures of worker control will be instituted simultaneously. In view of the difficulty of differentiating between the interests of one worker and the interests of another and between the types of worker interests involved in the usual employment relationship, ${ }^{57}$ it is also

\footnotetext{
Es "A dispensing power is a legitimate method of tempering the rigor of the law." Freund, ADMINIstrative Powers Over Persons and Property (1928) r33.

"The "Work or Fight" order of the Provost Marshal General in the First World War followed this approach, specifying certain occupations (i.e., the "service" occupations) as nonproductive, and rendering all men so engaged liable for immediate induction regardless of dependency status. SECOND Rep. of Provost Marshal General (I9I8). A similar approach occurs in the General Limitation Orders ( $L$ orders) and Material Orders ( $M$ orders) of the present WPB, the production of certain articles or the use of certain scarce materials in their production being restricted or prohibited. See note 28 , supra.

66 Compare the standard for allocation of shortage materials and facilities in $\$ 2(a)$ of the Priorities Act, as most recently amended by the Second War Powers Act. Pub. L. No. 507, 77th Cong., 2d Sess. (March 27, 1942), i.e., "as he [the President] shall deem necessary or appropriate in the public interest and to promote the national defense."

CD The measures of employer-control discussed previously could be fortified by applying penalties for their enforcement against workers as well as employers Since the worker's and the employer's rights would in each instance be correlative, restraints upon the worker's rights would have the same legal aspects as restraints upon the corresponding rights of the employer. For this reason, and because imposition of penalties upon the worker as well as the employer would deprive the measure of most of the administrative advantages of employer, as contrasted with worker, controls, they require little discussion. Nevertheless, Canada has thus far consistently followed this approach. See note 3 supra, and notes 57 and 60 infra.

${ }^{67}$ Any such differentiation must necessarily be" arbitrary. Canada, for example, has recently taken steps to prevent persons presently engaged in agriculture from securing other than farm employment.
} 
probable that the measures discussed separately below, would be instituted simultaneously.

(a) Freezing in employment. Freezing in employment involves restriction of the right of a worker to leave his employment. The purpose of such a measure is to preserve for certain essential production its current labor supply and to prevent the labor waste incident to uncontrolled labor turnover. Consistently with that purpose, the measure would presumedly be applied only to critical workers, conservation of whose labor is a legitimate concern of the Government. Whether the public interest would reasonably extend to the prevention of labor waste incident to the turnover of critical workers not engaged in essential war production, is a matter not free from doubt. The distinction between the Government's interest in this form of waste and its interest in waste of critical workers due to employer nonutilization is apparent; its interest in the latter is in the placement and full utilization of the workers in war production enterprises. If universal freezing is instituted, its strongest justification is the administrative one; it may be impossible to devise a workable procedure or a sufficiently precise standard by which employers and workers could ascertain or be informed whether or not they are engaged in activities deemed essential to the war effort; if that administrative difficulty is real and demonstrable, precedent exists for reliance upon it. $^{58}$

Since no essential legal difference exists between compelling a worker to remain in a particular employment with a private employer, and compelling an individual to accept a particular employment with a private employer, the constitutional issues involved in both measures will be discussed later. Upon principles already discussed in connection with measures of employer control, the public interest in the labor of critical workers is sufficient to justify all otherwise constitutional measures reasonably related to eliminating the waste of such labor caused by turnover. That labor turnover directly results in appreciable labor waste, and that freezing critical workers will curtail labor turnover, requires no demonstration.

A freezing program entails governmental control not only of a worker's right to leave his employment but also of an employer's right to discharge the worker. The unrestricted exercise of either right results in labor turnover. The right of an em-

\footnotetext{
Persons whose freedom of employment is thus restricted are those who were employed at farm work: on a certain date, i.e., the effective date of the regulation. Obviously, mere happenstance distinguishes farm laborers who are and who are not affected by the regulations, and, while the distinction is perfectly reasonable in the light of the broad purposes to be subserved, it is essentially arbitrary as respects each individual concerned. The Stabilization of Employment in Agriculture Regulations (P. C. 2251), Canada, Emergency Laws, Orders and Reg., pt. 37, p. 31. Simultancous imposition of a morc drastic form of worker-control such as compulsory transfers, discussed, infra, p. 457, would have permitted a more reasonable classification, i.e., one based on their qualifications or expcricnce as farm workers, and would have relieved the regulations of the arbitrariness inherent in its dependence on what is essentially an irrelevant factor-the engagement at farm work on a particular date.

${ }^{68}$ Cf. Bayside Fisch Co. v. Gentry, 297 U. S. 422 (1936); Jacob Ruppert v. Caffey, 25I U. S. 26.4 (1920); Purity Extract Co. v. Lynch, 226 U. S. I92 (1912); Dreyfoos v. Edwards, 284 Fed. 596 (S. D. N. Y. 1919), aff'd, 25 I U. S. I46 (1919).
} 
ployer to discharge a worker is no less subject to regulation and control in the public interest than is his right to hire or to fix the terms of employment. ${ }^{50}$

It should be noted that the right of a worker to quit and the corresponding right of an employer to discharge constitute primary factors in the shaping of their employment relationship. Simultaneous deprivation of the right to quit and the right to discharge in effect leaves the relationship without a rudder. Some Government control of the terms and conditions of employment, in a manner fair to both parties, is not only justified but necessary under the due process clause. It may therefore be expected that if freezing measures are adopted, such measures will be accompanied by incidental measures providing for governmental supervision of hours, wages, working conditions, disciplinary action and the like, or at least for supervision of certain changes therein. ${ }^{60}$

(b) Compulsory Transter. Under a compulsory transfer program, individuals are required to accept employment with a particular employer and the designated employer is required to employ the individual. Such a program necessarily entails freezing, i.e., restrictions upon the rights of both employer and worker to terminate the resulting employment.

Obviously and immediately presented is the question of the validity of such measures under the Thirteenth Amendment. ${ }^{01}$ Admittedly, such measures involve a novel form of compulsory service. ${ }^{62}$ Yet, assuming a national emergency which

${ }^{80}$ Compare restrictions upon employers with respect to the hiring, tenure of employment, and discharge of workers, prescribed in the National Labor Relations Act, 49 STAT. 452 (1935), 29 U. S C. 5158 (3), (4). Phelps Dodge Corp. v. NLRB, 313 U. S. 177 (1941).

${ }^{\circ 0}$ The order of the Canadian Privy Council promulgating "The Stabilization of Employment in Agriculture Regulations, 1942," effective March 23, 1942, supra note 57, in effect constitutes a freezing measure. These regulations seek to accomplish "freezing" indirectly by restraining workers in agriculture on the effective date of the order from obtaining employment elsewhere, and at the same time restraining prospective nonagricultural employers from hiring such a worker. The regulations do not restrict the employer's right to discharge an agricultural worker, nor the latter's right to quit a particular agricultural employer. A somewhat similar technique is followed in other orders of the Canadian Privy Council which forbid the entry into employment in specified nonessential activities (called "restricted occupations") of certain male persons, Order of March 21, 1942, and require employers to release critical workers requested by the Minister of Labour to transfer to essential work. Sec note 3, stipra.

${ }^{62}$ U. S. CoNST., Amend. XIII, provides in part: "Section Y. Neither slavery nor involuntary servitude, except as a punishment for crime whereof the party shall have been duly convicted, shall cxist within the United States, or any place subject to their jurisdiction."

${ }^{02}$ There are many early English statutes the object of which "was partly the suppression of vagrancy, but it was also gencrally considered a proper function of the police power to sccure, if necessary, by compulsory measures, to agriculture and industry an adequate and steady supply of labor." FrEUND, Police Power, $\S_{448}, c f$. $\S_{4} 08$. This author continues: "At the present day it is only necessary to refer to this kind of labor legislation in order to point out its unconstitutionality. The requirement would beyond any doubt be involuntary servitude forbidden by the Thirteenth Amendment of the Federal Constitution, and a statutory minimum term for labor contracts is an indirect form of compulsory service." England now has wartime statutes, regulations and orders which far eclipse the earlier statutes in their controls of workers and employers, e.g., Emergency Powers (Defense) Act (1940) $3 \& 4$ Gro. VI, c. 20; 5 \& 6 Geo. VI, c. 4 (I94I); Defense Regulations 54 (I940) (controlled undertakings) and $58 \mathrm{~A}$ (1940) (control of employment); The Essential Work (General Provisions) Order, I94I, S. R. 60, 194I, No. 302. See Hoague, Brown, and Marcus, supra note 3, at 69 et seq.

Clearly distinguishable are some of the so-called Counsel of Defense statutes enacted by several states during the First World War requiring persons to be gainfully employed, the restraint being 
warrants such measures, in only one material respect have the forms of compulsory service heretofore sanctioned under the Thirteenth Amendment differed from the compulsory service now under consideration, to-wit, all found precedent in our own or pertinent English history. ${ }^{83}$ The lack of historical precedent for the measures here considered can be readily explained by the novelty of the circumstances which may confront the nation; while such precedent would be useful, its absence per se should not constitute a constitutional obstacle. ${ }^{64}$

Underlying every type of compulsory servitude heretofore upheld is the fundamental element, often described as the justifying element, that the servitude was in the public interest. ${ }^{65}$ Underlying every type of compulsory servitude held prohibited

against idleness rather than upon the individual's choice of employment. The statutes are collected in Hoague, Brown, and Marcus, supra note 3, at 60. One of these, W. Va. Acts 1917, 2d Ex. Sess., c. 12, was held unconstitutional in Ex parte Hudgins, 86 W. Va. 526, 103 S. E. 327 (1920), principally on the grounds that it was not the vagrancy law it purported to be because it was not conditioned on financial distress, and that the state had no war powers. The latter argument seems unsound. Gilbert y. Minnesota, 254 U. S. 325 (1920); State v. McClure, 7 Boyce 265, 105 Atl. 712 (Del. x919). Other similar statutes, more in point, provided for assignment of the idle individual to some useful employ. ment upon terms agreed upon by the assigning state officer and the prospective employer. E.g., Md. Laws Ex. Sess. 1917, c. 33; Del. Laws 1918, c. 3. The Delaware statute was held constitutional in State v. McClure, supra, the court recognizing its true purpose and upholding it under the state's war power. The court added: "Nor do we consider it necessary or important to determine what in times of peace may or may not constitute involuntary servitude as meant by the Thirteenth Article of the Constitution." State v. McClure, supra at 713. The Maryland statute, still in effect, provides claborate safeguards for the rights of individuals. Under all such statutes, the individual is little restrained in choice of employments and presumedly could with impunity leave the assigned employer for other useful employment.

${ }^{\text {c3 }}$ Historical considerations were relied upon almost exclusively to sustain compulsory service under seamen's contracts, Robertson v. Baldwin, 165 U. S. 275 (1897), and on public roads, Butler v. Perry, 240 U. S. 328 (I916). Cf. Kneedler v. Lane, 45 Pa. 238 (1863).

${ }_{84}$ The fallacy of the historical argument was pointed out by Harlan, J., dissenting in Robertson $v$. Baldwin, 165 U. S. 275,288 (1897). From one point of view, the fact that a particular form of involuntary servitude was well known prior to the Thirteenth Amendment would evidence an intent that the Amendment apply thereto-otherwise, there should have been a specific exception. The effect of the decisions has, strangely enough, been to confine the Amendment to special types of involuntary servitude well known at the time of its adoption, such as peonage and long-term contracts for personal service, to render it inapplicable to other equally well-known servitudes, and to leave open its application to any completely novel type of servitude which could not have been in contemplation when the Amendment was adopted. In this light, then, lack of historical background may as well be an asset as a liability in the constitutional argument.

os Types of involuntary personal service recognized as constitutional may roughly be divided into two categories-compulsory service directly to the state, and compulsory service directly to, or immediately benefiting, private persons but required in the public interest. Included in the first eategory are building and maintaining public roads, Butler v. Perry, 240 U. S. 328 (rg16); jury duty, cf. State v. Cantwell, I42 N. C. 604,55 S. E. 820 (1906); assistance in making an arrest, cf. Dougherty v. State, ro6 Ala. 63, I7 So. 393 (I895); attendance as witness, cf. State v. Henley, 98 Tenn. 665, 4r S. W. 352 (1897); compulsory military service, The Selective Draft Law Cases, 245 U. S. 366 (1918); U. S. v. Sugar, 243 Fed. 423 (E. D. Mich., 1917); civil service as a public officer, Crews v. Lundquist, 36x Ill. 193, 197 N. E. 768 (x935); London v. Headen, 76 N. C. 72 (1877); MEcheM, Tre Lsw of Puslic OFficers (1890) $155 \mathrm{et}$ seq. In the other category might be included service as a scaman, Robertson v. Baldwin, I65 U. S. 275 (r897); cf. Southern S. S. Co. v. NLRB, 62 Sup. Ct. 886 (1942); minors under apprenticeship, Kennedy v. Neara, 127 Ga. 68, 56 S. E. 243 (1906); see Case of Mary Clark, Blackf. 122, 123 (Ind. 1821); service in certain private employments whose abandonment would endanger public safety, Freund, Police Power (1904) \$452. Mr. Freund concludes an interesting discussion on this subject as follows: "We may then conclude that in a business affected with a public interest, the violation of a contract of service which is essential to the carrying on of the business, may, 
under the Thirteenth Amendment, is the fundamental element that the servitude was in the interest of private persons. In those cases in which the servitude in question was servitude to the State (as has been most frequently the case) little or no necessity existed for inquiry as to the presence of an adequate public interest. ${ }^{66}$ The duty to serve the State which the courts have emphasized in these cases appears to be but another form of expression for the underlying principle that where private rights and public interests conflict, the latter must prevail. ${ }^{67}$ Though the outstanding instance of compulsory service under a private contract of hire, that of a seaman, was justified on historical grounds, ${ }^{68}$ the underlying public interest in the seaman's servitude is apparent and has not escaped judicial notice. ${ }^{69}$

If, by reason of withdrawals of manpower for the armed forces, the stringencies in the labor market render essential some program to assure the availability of the maximum possible number and type of workers required to maintain essential civilian and war production activities, the existence and the legitimacy of a paramount public interest in whatever involuntary servitude is inherent in compulsory transfer and freezing measures seems clear. Under such circumstances, assuming proper worker safeguards, such compulsory servitude, though ostensibly servitude to the employer, is more realistically servitude to the State. Its exclusive purpose is to promote the public, not the employer's interests. The governmental restrictions upon the employer's ordinary rights and privileges in the employment relationship, which accompany the freezing and transfer measures, must clearly disprove the existence of any of the elements which characterize servitudes held unconstitutional by the courts. If the Government enters this field of labor mobilization, the resulting compulsory relationships between employer and worker will probably bear only token resemblance to the usual employment relationship; such servitude as exists will be imposed alike upon employer and worker, and both in a more real sense will be servants of the Government. ${ }^{70}$ Objections to these measures under the due process

as a matter of constitutional power, be punished." Freund, op. cit. supra, at 483 ; compare note 62 supra. Several state statutes limit the right to strike in industries affected with a public interest. E.g., Mich. Pub. Acts 1939, Act No. 176; Minn. Stat. (Mason Supp. 1940) \$\$4254-26 and 27; Colo. AnN. Stat. (1935) c. 97. Defense work was ruled "affected with a public interest" within the meaning of the Michigan statute, supra, in Mich. Att'y Gen. Op. No. 18503. See comments (1940) 40 Mrch. L. REv. 1041, 1065 .

${ }^{\circ}$ Compare the summary dismissal of the involuntary servitude objection in The Selective Draft Law Cases, 245 U. S. 366 (19r8), with the laborious arguments in Robertson v. Baldwin, 165 U. S. 275 ( 1897 ). The dissenting opinion in the Robertson case recognized that "involuntary service rendered for the public, pursuant as well to the requirements of a statute as to a previous voluntary arrangement, is not, in any legal sense, either slavery or involuntary servitude." Id. at 298. While this statement was made to distinguish soldiers and sailors from civilian seamen, it suggests that the dissent failed to recognize the public interest in the servitude involved.

${ }^{67}$ Cf. Nebbia v. New York, 29 I U. S. 502 (1934).

${ }^{68}$ Robertson v. Baldwin, 165 U. S. 275 (I897).

${ }^{00}$ Hume v. Moore-McCormack Lines, I2I F. (2d) 336,345 (C. C. A. 2d, 194I).

70 The "essence of involuntary servitude" prohibited by the Thirteenth Amendment is "that control by which the personal service of one man is disposed of or coerced for another's benefit." Hughes, J., in Bailey v. Alabama, 259 U. S. 219,238 (IgII). It precludes serfage, vassalage, villenage, peonage "and all other forms of compulsory services for the mere benefit or pleasure of others." Field, J., dissenting in Slaughter House Cases, 16 Wall. 36, 90 (U. S. 1873). Slavery has been variously defined 
clause, insofar as they are based on the subjection of the worker to the employer, or vice versa, must be considered in the light of the principles heretofore discussed with respect to the Thirteenth Amendment; indeed, protection of the individual from the State is more properly the function of the Fifth Amendment than of the Thirteenth.

The amenability of many employers' peacetime rights to suspension and restriction by the Congress acting under its war powers has already been discussed. Compulsory transfer and freezing measures, from the employer's standpoint involve suspension or restriction of the employer's right to enter into, to terminate, and to fix the terms of an employment relationship. Insofar as all these partake of property rights, they are no less subject to governmental control than are those of the property owner during time of war. And just as the goods or facilities of the property owner cannot be taken or diverted to a public use without just compensation, ${ }^{71}$ so an employer may not be required, under a freezing and transfer program, to enter into, or to refrain from terminating, an employment relationship, the terms and conditions of which are so unconscionable as to amount to a taking of his property. Hence, either the interests of the employer must be equitably protected in the fixing of the terms and conditions of employment, or, if not so protected, some way must be found to compensate the employer for any possible loss.

To the extent that the right to employ, supervise or discharge a worker partakes of a personal, rather than a property, right, suspension or restriction of the employer's rights is no different in principle from suspension or restriction of the corresponding rights of the worker. The right of the employer to discriminate, in the hiring process, on the basis of age, sex, color, nationality, etc., is, of course, a personal not a property right.

It has sometimes been said that the right of the worker to proffer or withhold his services is in the nature of a property right; ${ }^{72}$ from this it might be argued that compulsory service constitutes a taking for a public use within the meaning of the Fifth Amendment, and hence to require just compensation. ${ }^{\mathbf{7 3}}$ Though the worker's right to work or not to work for another under the usual employment contract may partake of a property right, as noted above, the relationship that results from com. pulsory service of the type involved under compulsory transfer and freezing measures differs materially from that which is the subject of an ordinary contract of employment. Though the worker's right may be a property right so far as the employer is concerned, his rights vis-a-vis the State are quite different. In compelling a worker to

\footnotetext{
but always to include the concept of service for the benefit of the master. Civil Rights Cases, Iog U. S. 3 (1883); Plessy v. Ferguson, 163 U. S. 537 (1896). "The great purpose in view was liberty under the protection of effective government, not the destruction of the latter by depriving it of essential powers." Butler v. Perry, 240 U. S. 328, 333 (r916). The right of the state to demand services of its citizens, in peace as well as in war, and the corresponding duty of the individual to serve was entrenched at common law. "The right stands on at least as high a necessity as the right of eminent domain." London v. Headon, 76 N. C. 72, 75 ( 1877 ); Throop, Public OfFicens (1892) \$5165-167.

${ }^{71}$ Int. Paper Co. v. U. S., 282 U. S. 379 (1931); U. S. v. Russell, 13 Wall. 623 (U. S. 1872).

${ }^{12}$ Cf. Adair v. U. S., 208 U. S. 161 (1908).

${ }^{23}$ It was so argued in Butler v. Perry, 240 U. S. 328, 333 (x9x6).
} 
perform services in the State's behalf, the State is not "taking" the worker's property but is asserting its paramount right to restrict his freedom and to control and regulate his conduct in the public interest. And it is well settled that an individual may be compelled to serve the State without any compensation whatsoever. ${ }^{74}$ The services rendered pursuant to proper compulsory transfer and freezing measures are rendered to the State, the employer in this sense being a convenient agent through whom the Government exercises its powers.

The more difficult questions of due process will arise, not with respect to the power of the Government to compel an individual to accept certain employment in the public interest, but with respect to the manner in which that power is exercised. A primary problem is the mutual protection of both worker and employer. It would obviously be unconscionable for the Government to compel a worker to work for an employer and then to abandon the field, leaving the worker at the mercy of the employer whose interests are essentially in conflict with those of the worker. Both the Thirteenth and the Fifth Amendment require governmental control of the terms and conditions of employment under such circumstances in the worker's behalf; the latter amendment requires corresponding control for the protection of the employer. It is therefore to be expected that any enabling legislation providing for a compulsory transfer and freezing program will either authorize or will have been preceded by, appropriate controls over wages, hours, and conditions of work; such controls may take a variety of forms, too numerous and varied to discuss here. The fundamental consideration must be the interest of the public, though that interest should in the usual case coincide with the interests of the worker and the employer. The principal danger is that in operation, a particular action resulting in the worker's or employer's detriment may be construed as taken in the employer's or worker's, rather than in the public, interest.

\footnotetext{
"Personal services, as contrasted with property, may be "taken" by the state without just compensation. Butler v. Perry, 240 U. S. 328 (I916); Crews v. Lundquist, 361 Ill. 193, 197 N. E. 768 (1935).
} 